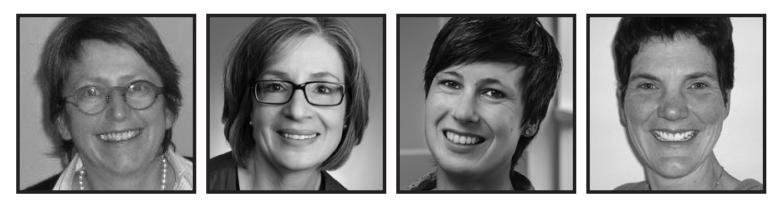

\title{
Encouraging a Curiosity of Learning: Reflecting on Arts-Informed Spaces Within the Classroom
}

\author{
Vera Caine, Susan Sommerfeldt, and Charlotte Berendonk, \\ University of Alberta \\ Roslyn M. Compton, Saskatchewan Polytechnic
}

\section{ABSTRACT}

It is through imagination that we create arts-informed inquiry spaces of learning. Our teaching practices and research include being awake to would-be artistry by encouraging a curiosity of learning. In these spaces we have learned to be open to surprise, play, and possibilities. As we make arts-informed methods integral to teaching and learning, we purposefully engage; in our classroom is where experiences call forth inquiry. In this paper we make visible four common threads. These threads include: considering the ontological and epistemological underpinnings of our practices; the significance of relationships; playfulness, imagination, and world travelling; and reconsidering our teaching and research practices.

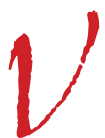

era and Susan remember a recent time when they drove out to the old log house, situated at Strawberry Creek just west of the city where we live. The road still wet from the warm January temperatures made the drive far less treacherous than it could be on the cold and stormy winter days we have come to expect at this time of the year. Their eyes were drawn to the sky that dances in colors of orange and blue, like only an Alberta sky can when inviting dusk. The weekend was dedicated to some sustained writing time, necessary to move ideas onto paper and to further inquire into the experiences they have had alongside students in classrooms, or as researchers using arts-based methods. Our experiences spanning personal and 
professional landscapes are diverse, and our lives as researchers and teachers often blend in unexpected ways. Yet, there is also a shared sense of inquiry and learning across our experiences as teachers and researchers, inquiry that draws on art to engage in ways that help us think with lives.

Drawing upon Eisner's (2002) emphasis of the importance of artistry in learning, we attempt to create a space that fosters students' and our abilities to take risks, to play, and a space that welcomes reflections. We always begin by situating learning in the experiences of our lives, and through risk taking and play, live alongside others as they begin to imagine the world differently. In this process we often draw upon theatre, photography, poetry, and creative nonfiction writing. In part we draw on arts-informed methods; as Polanyi (1958) reminds us, we know far more than we can tell. As we make arts-informed methods integral to our teaching and learning, we purposefully engage in performance, where experiences call forth inquiry.

In this paper we make visible how we engage in arts-informed inquiry spaces of learning. Thinking with our stories, we will highlight some of our learnings. We will first attend to our experiences in a classroom alongside first-year university nursing students, where questions of personal and professional identity were raised through the use of arts-informed methods. We then turn to some of our research and explore how we engaged in poetry to inquiry into our experiences. We look for common threads across these experiences and what has shaped them over time, in diverse places and contexts. We conclude with possibilities of arts-informed inquiry spaces for learning landscapes.

\section{Setting the Context}

Inquiring, learning, wondering, and teaching come together in interactions with students and others in spaces of inquiry along the pathway to deepening understanding and meaning. In our role as educators, specifically within faculties of nursing at universities, we are aware of providing such space within the structures of preparing students to enter a profession. Over the course of our careers we have often encountered many ways of curricular that are mandated. This at time has also been extended to prescribe ways in which we teach. Our teaching practices include being awake to would-be artistry through encouraging a curiosity of learning for students and ourselves. 
By exploring our evolving selves, we see ongoing moments that build on experiences, views, and values that influence our teaching practices. The aim, as articulated by Walsh, Bickel, and Leggo (2015), is to "be present to the possibilities and potentialities that exist at the intersections of the artistic and the contemplative.

"It is to be present to the moment as well as "open to what is not yet known" (p. 1).

Vera remembers:

It was the first class of the new term and I had been nervous and excited to welcome a group of first year students. As I prepared for the class, my eyes were turning towards my bookshelf. Besides the usual textbooks, were the many children's books and stories that so often helped me start a class. This class was no different and I wondered how I could set the tone that would allow students and I to begin our class in a relational way. What stories and images would draw forth their and my experiences? How could we shape the space in which we could learn from each other?

\section{Experience in the Classroom}

For us, arts-informed teaching practices are not reduced to moments of creativity. Rather, thinking with arts-informed methods to create multiple avenues for conversations infuses our teaching practices. These practices become central and are core to our being as teachers.

In a first clinical experience, nursing students began their work of teaching wellness principles and healthy behaviour practices in an elementary/primary grade school. For most of the nursing students, it was the first time they had been back in an elementary school since their childhood. Following the first few weeks of the clinical placement, Susan structured an exploratory session using image theatre during class time. Image theatre, under the umbrella of Boal's Theatre of the Oppressed (1985), was produced by the students using each other as characters in a frozen scene depicting a moment in their experience, as nursing students, teaching a health topic. Each student took turns creating their scenes, exploring the constructed elements of place, spaces, facial expressions, body positions, proximity of the characters, and the distances between student and teacher. The students fashioned themselves as teacher, portrayed by a character requiring them to revisit their own gestures, expressions, and body language. Characters were molded and staged by the student both as an expression and as an analysis of their experience. Learning occurred while constructing 
the image and further while discussing the image with the audience of other students. The use of theatre had created a space of risk for the students in which to ask questions of each other such as, "Why do you have so much distance between yourself and the kids?" or "Do you think you look bossy?" This, in turn, opened up new spaces for conversation.

The imagery of theatre in everyday life (Goffman, 1959) uses dramaturgical analysis of commonplace encounters to frame social interactions, actors, and settings. Having students explore their performances in a new role within an old setting brought forward a place to consider feelings and behaviours that were not immediately apparent in their verbal or written considerations of their experience. Much like Barone and Eisner's (1997) metaphorical journey into space that takes an astronaut to the moon and back, using theatre in the classroom took the students from their lived-in world to an aesthetic place that is close enough to be recognized, yet far enough away to hold a new context. The new context, a "virtual reality," brings a "fresh outlook, perspective, paradigm and ideology" (p. 74).

Susan recalls her learning alongside students and writes:

I was introduced to the magic of live theatre as a child. The idea of creating an imaginary spot that everyone else accepted as a legitimate reality fascinated me. The actors became someone else-a character, in a place created by sets and props enhanced by mood influencing lighting and theatrics. The audience suspended reality and with shared imagination and story making, a transformation occurred. The power of aesthetic experience introduced new understandings beyond mere entertainment in a magical way.

The transformational power of theatre to create a reality and offer avenues to make meaning has become part of Susan's pedagogy and is intertwined with her research. Susan sees opportunities with students to use theatre games, attend plays, watch and discuss movies, create scenes with multiple endings, and enhanced simulation as a counterpoint to other academic teaching strategies. As with other arts-informed learning, nursing "knowledge" takes on a new perspective of information because of the aesthetic experience (Marshall, 2014). 


\section{Experiences in Research Spaces}

Roslyn teaches nursing students at a different institution. As she listens carefully to Susan's experiences in the classroom, she begins to reflect on where her interests in gerontology began. This interest has become a large part of her research. She recounts:

I connect it to my lifelong journey of co-composing stories alongside Grandma. Her stories have been ones of extremes. She has experienced times of richness and poorness; joy and loss; love and isolation but most of all, it has been her life. I have traveled many roads with her and taken detours along the way, and at each new place we came to, I learned from her wisdom, kindness, patience, and respect. In deepening my understanding of what it meant to grow older, I found myself playing with words and poetry. Found poetry (Butler-Kisber, 2002) provided me with an opportunity to say something, yet leave space for other peoples' words. The incomplete sentences, the white spaces on the page, changing fonts, and positioning of words in relation to each other and the page, might invite others to tell their stories. I believe sometimes, these stories may be the hard to tell stories that never appear complete. It is here I remember a poem I wrote about feeling alone and loneliness.

Situated within a context of research involving older adults and their experiences in relation to place, Roslyn began to inquire into the experiences she had alongside her participants using found poetry. She wrote:

alone

LONELINESS

I am not much older than you are

what if we measured life not in years, but in the moments of aloneness

Writing found poetry has led Roslyn to explore other mediums to deepen her understanding of others and herself. As part of her research she began to work with photographs, which provided her with spaces for imagination and playfulness. In this photograph showing an image of her Grandma at a young age, Roslyn wondered: "Who is Grandma saluting to and what is her relationship with the photographer? How did her life in a small farming community, many miles from the sea, change her?" 


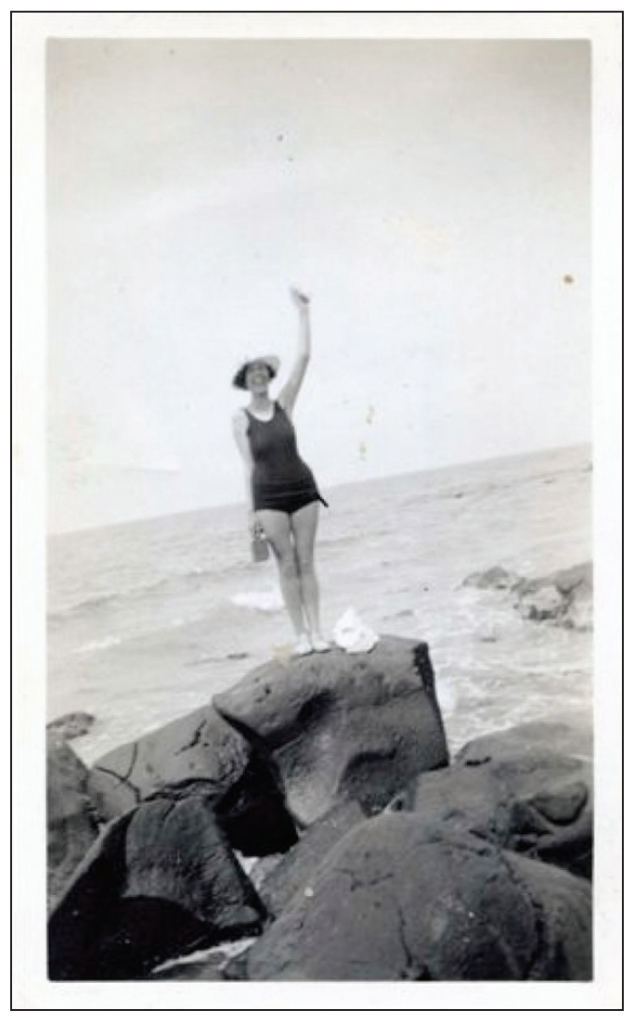

Fig. 1: Roslyn's grandmother

As Roslyn shares her poem and photograph of her Grandma, Charlotte starts to enter the conversation.

As a child I was always fascinated by stories told by my grandmothers; stories of times unfamiliar to me and yet connected through our shared family history. A similar fascination was in the foreground in my professional landscape as a geriatric nurse. I was interested in peoples' narrations and wondered about life experiences of people living in long term care facilities. I was often frustrated because I felt a disruption of people's life narratives and identities when they were being institutionalized and at risk of being de-storied.

As this dialogue happens, Vera begins to rewrite the poem. And in listening to the poem, we recognize that arts-based methods create spaces of possibilities to counter the silent and silenced stories. 
storied as alone

even so I am not much older than you are,

I too have come to know the impact of being institutionalized

what would change if

we measured life not in years, but in the moments of

possibilities

What begins to happen is linked to a generative way of engaging with lives and experiences. Generative spaces that opened up through the use of artsinformed methods.

\section{Threads Across Our Experiences}

The log house on the Alberta prairie landscape started to have familiar rhythms and the voices of others carried Vera and Susan back to some of the memories of their experiences. Experiences that continue to ripple into their lives and practices as teachers, researchers, and as people in relation. As we think with our experiences of making arts-informed methods central to our practices, we can see resonances across our experiences. Clandinin and Connelly (1998) wrote,

[t]he promise of storytelling emerges when we move beyond regarding a story as a fixed entity and engage in conversations with our stories. The mere telling of a story leaves it as a fixed entity. It is in the inquiry, in our conversations with each other with texts with situations with other stories that we can come to retelling our stories and reliving them. (p. 208)

This ability to retell and relive our experiences is important to us, as it allows us to discover dissonances and resonances that shape who we each are and are becoming. Arts-informed practices can enlarge the possibilities to this, as it creates the possibilities to draw forth and in embodied knowing. In the following sections we will turn to resonant threads: being grounded ontologically and epistemologically; making relationships central; playfulness, imagination, and world traveling; and reconsidering practices in teaching and research.

Being grounded ontologically and epistemologically. Over time we have learned to ground our work by returning to the ontological and epistemological underpinnings of our practices, which raise questions for us about what we know and how we have come to know. Working within a pragmatist tradition (Dewey, 2005), we see the importance of experience and it is critical to recognize the continuity of experiences. 
Like other pragmatists, we see our work as future oriented, recognizing that each one of us is always living in the midst (Clandinin \& Connelly, 2000). Greene (1993) calls us to think about, that

even in the small, the local spaces in which teaching is done, educators may begin creating the kinds of situations where, at the very least, students will begin telling the stories of what they are seeking, what they know and might not yet know, exchanging stories with others grounded in other landscapes, at once bringing something into being that is in-between. [...] It is at moments like these that persons begin to recognize each other and, in the experience of recognition, feel the need to take responsibility for one another. (p. 218)

Like Greene (1993), we see educators not just as teachers, but as people who exist at the intersections of many categories and roles; people who strive to create a space in which others can be wide awake and continually evolving, becoming. Roslyn draws our attention to the importance of the experiences in her own life, alongside her Grandma. These experiences, even after the death of her Grandma, do not become fixed stories. Instead, the telling and retelling of these stories show how the stories are still working on Roslyn. The stories continue to shape Roslyn's practice as a nurse and as a teacher, where arts-informed methods like photography open up spaces to consider intergenerational reverberations (Young, 2003), and reconsider what age and aging means in the context of relationships. Rather than theoretical ideas, for us experience is always the starting point for entering relationships with participants and students. In a recent clinical course, Roslyn invited the students to engage in photography work to explore their notions of what it means to grow older. In a subsequent class they were then invited to respond to this and explore how they would practice nursing in relation to their understanding of what it means to grow older.

Making relationships central. Through our research practices as narrative inquirers, we have come to know that we do not stand at a distance from our participants; rather, we actively negotiate relationships (Clandinin \& Connelly, 2000). These relationships are central and necessary to our work, as we often wade into the muddiness and murkiness of participants' and our lives. Thinking about Roslyn's invitation to students to reflect on what it means to grow older creates a possibility for the students to see that their understandings shaped how they engaged with older adults and that their lives were not separate from those they encountered in practice. It is here, in the messiness, that matters of the greatest human concern are found and where we wrestle with questions that often reflect social inequities and challenges. To wrestle with these questions not only requires commitment to the questions, but also to participants or students. 
As we stay in relation and make relationships central to all of our practices, we see how much our work, as researchers and teachers, has drawn our attention to resonances that live within these relationships. Resonance requires us to pay attention to

how I listen for the knowing of persons whom I [am in conversation with], how I imagine their lives, how I sense the limits of their words to convey what they feel and know, how I sense my own inability to comprehend what they know and learn even as they speak. (Neumann, 1997, p. 91)

We are mindful that as we enter lives and engage in relational experiences that there is always the possibility to undo and reconfigure participants, students, and ourselves in relationships. This speaks to the connectedness of lives and the vivacity of being in relation. Yet this too requires us to be willing and able to imagine a world other than our own and to be able to see difference (Andrews, 2007). For us, this way to imagine is closely linked to arts-informed practices.

Playfulness, imagination, and world traveling. To imagine a world other than our own it is important to be playful, and to engage in imagination and world traveling. Arts-informed methods allow us to engage in world traveling and to explore the resonances that live between lives. Our intent is always to bring forth personal knowledge, values, feelings, and beliefs; to identify them and to name conflictual ones; to begin to imagine otherwise; and to enter relationships and the possibilities to share experiences.

Stories are not only the way in which we come to ascribe significance to experiences [...] but also they are one of the primary means through which we constitute our very selves [...] we become who we are through telling stories about our lives and living the stories we tell. (Andrews, 2000, pp. 77-78)

And while our classrooms allow us to create reciprocal worlds, places where we share stories of practice and stories in practice, they remain only the beginning places to explore and imagine nursing practice and professional identity. Arts-based practices open up places to remember, tell and imagine stories, but they can also bring experiences to the forefront that were untold, silenced, or invisible. In these moments we, as researchers and teachers, must remain attentive, playful, and open to surprise. Vera recalls vividly how students began to share stories of attending to their own family conflicts, to their experiences of difficult child birth, to the loss of their grandparents, or to the times in which they were most happy. Many of these stories were expressed in poetry, letter writing, or images that they had created. 
Engaging in playful practices in education invites us, as educators, to work from a position of vulnerability. To Brown (2012), vulnerability is "uncertainty, risk, and emotional exposure" (p. 34) and is central in meaningful human experiences. It is the birthplace of courage and creativity (along with other desirable traits). Vulnerability in teaching involves being open to the risks that accompany arts-informed methods. Art is not didactic, but instead draws on characteristics of "complexity, ambiguity, multilayered meanings, and richness of imagination" (Jackson, 2007, p. 181). Art opens spaces.

Lugones (1987) refers to playfulness as an attitude "that carries us through the activity, a playful attitude, turns the activity into play" (p. 16). This kind of playfulness asks us to stay wakeful to surprise. For Lugones playfulness is critical to world traveling, where we become fully engaged with the other. Through world travelling she recognizes that,

[t]here are "worlds" that we can travel to lovingly and traveling to them is part of loving at least some of their inhabitants. The reason why I think that traveling to someone's "world" is a way of identifying with them is because by traveling to their "world" we can understand what it is to be them and what it is to be ourselves in their eyes. (p. 17)

\section{Susan recalls}

...questions that tempered my initial uses of theatre in the classroom. During a seminar with twelve nursing students early in their program, the conversation centred on obesity in adolescence. I knew that this presented an opportunity for a theatre activity to influence learning. We could create a short scene using components of forum theatre where conflict can be dismantled and then reassembled using new perspectives and insights. Despite these possibilities, I hesitated. Will the students engage? Can I facilitate this? Is it worth the risk? I did not know what the students' experiences would be or what learning might emerge. I remember purposefully making a decision to take the risk. We created a scene within an imaginary play, staging a teen and parent interaction, switching student actors and rerunning the scene a number of times. The conversation that followed had a richness and student investment, which had eluded the earlier classroom discussion. It awakened an emotional connection, a completeness to an experience of learning, seen by Dewey (2005) as an esthetic "rounding out."

Susan realized her teaching required reinventing herself as a fundamental component of a dynamic teaching practice. As Susan engaged in teaching, she realized that she was strongly influenced by her role as a mother of a number of children, 
a role that at times overlaid a maternal sense that conflicted with the risk taking she saw as necessary in her classroom practices. Arts-informed teaching invites risk taking in both student and teacher by disrupting linear thinking and opening ways of exploration and imaginative interpretation. It reframes issues and calls to meaningmaking, necessary for understanding complexities in health care. Being alongside students seeking identity and capability as future practitioners in nursing asks of Susan to also reflect and refine her pedagogy.

As we think with Susan and Roslyn's experiences, we can see that the educative spaces both within the classroom and in research hold possibilities of becoming and they are a place for imagining. Play in this way is a "medium that allows us to bring forth our embodied knowing" (Caine \& Steeves, 2009, p. 5). At the same time we are mindful, that,

[b]y attending to this playfulness, our spaces of knowing enlarge and spaces of possibility are never ending; yet embedded in these possibilities is also a recognition how difficult it is to stay in relation, to remain wakeful to the tensions and boulders of the landscapes and stories we live within. (p. 1)

While Susan was initially drawn to arts-based methods in the classroom as a way to add to her teaching tools, she realized that it required a much more fundamental shift in her practice to create spaces for playfulness and imagination. This was important as

[i]t is the notion of play within imagination that helps us move inside the stories of others, of being and becoming. Play is a medium, which allows for the exploration of self; while at the same time the imagination can never "take leave of the other" (Kearney, 1998, p. 218). Imagination, Kearney (1988) argues, "needs to be able to laugh with the other as well as to suffer" (p. 367). In this laughter and suffering, this play with the other, our imaginings in relationship are brought into the present time and space. (Caine \& Steeves, 2009, p. 5)

In these moments Susan realized that imagination is also a form of embodied knowing (Sarbin, 1998, 2004). This way of being is supported by arts-informed methods that often bring forth uncertainties and possibilities of new understanding. Learning in this way is not predetermined.

Reconsidering practices in teaching and research. Our classrooms allow us to create reciprocal worlds alongside our students and ourselves, spaces where we share stories of practice and stories in practice. It is often the beginning place to explore and imagine differently, a place of fragility and vulnerability. In many ways, 
[a]rtistry is important because teachers who function artistically in the classroom not only provide [students] with important sources of artistic experience, they also provide a climate that welcomes exploration and risk-taking and cultivates the disposition to play. To be able to play with ideas is to feel free to throw them into new combinations, to experiment, and even to 'fail.' It is to be able to deliteralize perception so that fantasy, metaphor, and constructive foolishness may emerge. (Eisner, 2002, p. 162)

Encouraging students and research participants to be involved in arts-based practices builds understanding of schema that may not fit students' existing frames of reference. In many ways it helps them and us to recognize that experiences and

...stories are inner things: you're interacting with a living story. The way western man is taught to read is to find the meaning, the symbols. Instead I say no, a story is not something you figure out the meaning of, but something you carry with you the rest of your life to talk back and forth with. (Sarris, 1997, p. 229)

Seeing stories as inner things, and as always in motion, shifts our attention to processes rather than outcomes, and opens opportunities for negotiating learning aims and objectives with students. By doing so, we are responding to the need for considering whole lives and recognizing life making as always in progress. Richardson's (2000) plea for writing as an act of inquiry reminds us of the importance of leaving blank pages, pages without lines, without pre-determined structures, plots, and answers. In attempting to explore the white spaces we recognize lives are lived in the midst, and sometimes we need a place to playfully imagine new possibilities. Arts-based practices, including writing, is a way of troubling certainty and cultivating multiple ways of seeing within the white space, where multiple dialogues reminds us nothing ever stays the same (Greene, 1995). As we come closer to the end of the current teaching term, we sit together and realize that in as much as we have come to know the students in new ways, we each are also deeply shaped. Vera returns to the poem she wrote as part of the first class activity that invited students to share a memory of their name. The students engaged in the activity after listening to Vera read the book, The Name Jar by Yangsook Choi (2001). Vera ended her writing of her poem with, "when I first came to Canada people pronounced my name differently and I often would not recognize it ... it was a constant reminder that I was not from here." She wonders now if this sense of uncertainty that she shared with the students at the beginning of class had shifted not only who she was in relation to them, but also had for the first time more clearly allowed her to position herself as an immigrant that struggled to make sense of her early immigration experiences. 


\section{Conclusion}

The lodge had turned quiet again and the sun shines through the trees. Vera was reminded of her and also Roslyn's poem and the profound connections between loneliness and possibilities. The poem and photograph of Roslyn's Grandma are the visible reminders that arts-informed methods, if integrated within the context of relationships, hold the possibility to imagine, play, and world travel, and most importantly shift the experiences of teachers, researchers, and students. It shifts who they are and are becoming. By entering new places in teaching and learning, we have the opportunities to share our stories of vulnerability and fragility, troubling certainty and imagining new stories. It is through these stories, the white spaces, the silence, the multiple dialogues, and the openness to risks, that we begin to think with our experiences and centralize arts-informed methods within our practices. They are no longer moments of creativity, rather teaching practices that invite a sense of inquiry, of learning from experiences, new avenues to conversations, and a way to help us think with lives.

\section{References}

Andrews, M. (2000). Introduction to narrative and life history. In M. Andrews, S. Day Schlater, C. Squire, \& A. Treacher (Eds.), Lines of narrative: Psychosocial perspectives (pp. 77-80). London: Routledge.

Andrews, M. (2007). Exploring cross-cultural boundaries. In D. Jean Clandinin (Ed.), Handbook of narrative inquiry: Mapping a methodology (pp. 489-511). Thousand Oaks, CA: Sage.

Barone, T., \& Eisner, E. W. (1997). Arts-based educational research. In R. M. Jaeger (Ed.), Complementary methods for research in education (pp. 72-116) (2nd ed.). Washington: AERA.

Boal, A. (1985). Theatre of the oppressed. New York: Theatre Communications Group.

Brown, B. (2012). Daring greatly: How the courage to be vulnerable transforms the way we live, love, parent and live. New York: Gotham Books.
Butler-Kisber, L. (2002). Artful portrayals in qualitative research: The road to found poetry and beyond. The Alberta Journal of Educational Research, 48, 229-239.

Caine, V., \& Steeves, P. (2009). Imagining and playfulness in narrative inquiry. International Journal of Education and the Arts, 10(25).

Choi, Y. (2001). The name jar. New York: Dell Dragonfly Books.

Clandinin, D. J., \& Connelly, F. M. (1998). Asking questions about telling stories. In C. Kridel (Ed.), Writing educational biography: Explorations in qualitative research (pp. 202-209). New York: Garland.

Clandinin, D. J., \& Connelly, F. M. (2000). Narrative inquiry. Experience and story in qualitative research. San Francisco: Jossey-Bass.

Dewey, J. (2005). Art as experience. New York: Capricorn Books. (Original work published 1934). 
Eisner, E. (2002). The arts and the creation of mind. New Haven, CT: Yale University Press.

Goffman, E. (1959). The presentation of self in everyday life. New York: Anchor Books.

Greene, M. (1993). Diversity and inclusion: Towards a curriculum for human beings. Teachers College Record, 95(2), 211-221.

Greene, M. (1995). Releasing the imagination. Essays on education, the art, and social change. San Francisco: Jossey-Bass.

Jackson, A. (2007). Theatre, education and the making of meanings. Manchester, UK: Manchester University Press.

Lugones, M. (1987). Playfulness, "world" traveling and loving perception. Hypatia, 2(2), 3-19.

Marshall, J. (2014). Transdisciplinarity and art integration: Toward a new understanding of arts-based learning across the curriculum. National Art Education Association Studies in Art Education: A Journal of Issues and Research, 55(2), 104-127.

Neumann, A. (1997). Ways without words: Learning from silence and story in postholocaust lives. In A. Neuman \& P. L. Peterson (Eds.) Learning from our lives. Women, research, and autobiography in education (pp. 91-120). New York: Teachers College.
Polanyi, M. (1958). Personal knowledge: Towards a post-critical philosophy. Chicago: University of Chicago Press.

Richardson, L. (2000). Writing: A method of inquiry. In N. K. Denzin and Y. S. Lincoln (Eds.). Handbook of Qualitative Research (pp. 923-948) (2nd ed). Thousand Oaks, CA: Sage.

Sarbin, T. R. (1998). Believed-in imaginings. In J. DeRivera \& T. R. Sarbin (Eds.), Believed-in imaginings: The narrative construction of reality (pp. 15-30). Washington, DC: American Psychological Association.

Sarbin, T. R. (2004). The role of imagination in narrative construction. In C. Daiute \& C. Lightfoot (Eds.), Narrative analysis (pp. 5-21). Thousand Oaks, CA: Jossey-Bass.

Sarris, G. (1997). The truth will rise. In L. CrozierHogle \& B. Wilson (Eds.), Surviving in two worlds: Contemporary Native American voices (pp. 225-234). University of Texas Press.

Walsh, C., Bickel, B., \& Leggo, S. (2015). Arts-based and contemplative practices in research and teaching: Honoring presence. New York: Routledge.

Young, M. I. (2003). Pimatisiwin, walking in a good way: A narrative inquiry into languages identity. Unpublished doctoral dissertation, University of Alberta, Edmonton, Alberta.

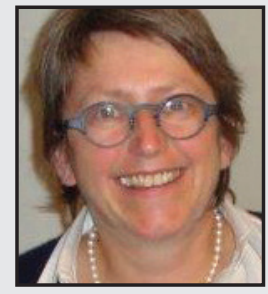

Vera Caine is an Associate Professor and CIHR New Investigator in the Faculty of Nursing at the University of Alberta. Vera engages in narrative inquiries alongside women living with HIV, aboriginal youth, and families in precarious housing situations. She has taught at the undergraduate level in first-year nursing courses focused on professional identity development or community health nursing. At the graduate level Vera has concentrated her teaching on qualitative methodologies and social justice practices. 


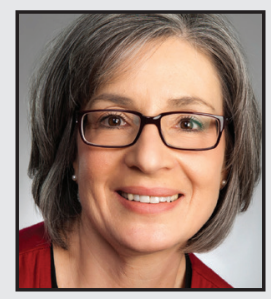

Susan Sommerfeldt teaches interprofessional healthcare team development and nursing theory at the University of Alberta in Edmonton, Alberta. Her teaching practice utilizes multiple arts-informed approaches in guiding students who are developing professional identities and abilities within health sciences educational programs. Susan's doctoral work explored the relational work of healthcare teams using forum theatre. She continues her interest in Theatre of the Oppressed in her teaching through theatre games and clinical simulations for embodied student-learning experiences.

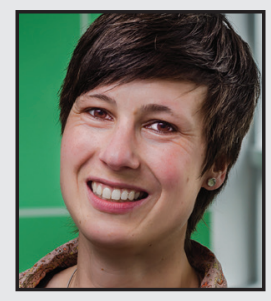

Charlotte Berendonk is a registered geriatric nurse. After completing her doctoral work in Gerontology at the University of Heidelberg in Germany in 2014, Charlotte has been doing her postdoctoral training with Vera Caine. Her postdoctoral work is funded by the German RobertBosch Stiftung in the program, "Changing viewpoints: Young researchers develop new ideas for a long and self-dependent life." One of her major research foci is narrative care, a nursing philosophy and intervention, strongly based on acknowledging persons as narrative beings and as embodied stories.

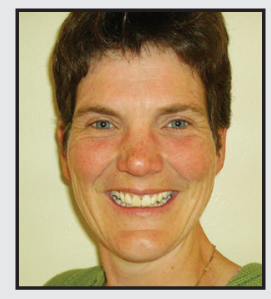

Roslyn M. Compton received her $\mathrm{PhD}$ in nursing from the University of Alberta and is currently a faculty member in the School of Nursing at the Saskatchewan Polytechnic, Saskatoon. Her research interests include older adults, aging-in-place, independence, narrative gerontology, and narrative care. Roslyn's work recognizes the importance of understanding older adults' experiences in relation to place and identity, and how social, cultural, and institutional narratives influence the stories told. She currently leads two research projects related to understanding older adults. 